\title{
Strategi KPU Kabupaten Bogor dalam Meningkatkan Partisipasi Pemilih pada Pemilihan Umum Tahun 2019
}

\section{Strategy from Bogor Regency KPU in Increasing Voter's Participation in the 2019 General Election}

\author{
Triana Pertiwi $^{\text {a, }}{ }^{*}$, Siti Rahmawati ${ }^{\text {b, } 2}$ \\ ${ }^{\mathrm{a}, \mathrm{b}}$ Fakultas Ekonomi dan Manajemen, Institut Pertanian Bogor, Indonesia \\ ${ }^{1}$ wiezy3110@gmail.com*; ${ }^{2}$ sitirahmawatiipb@gmail.com \\ *korespondensi penulis
}

\begin{tabular}{ll}
\hline Informasi artikel \\
\hline Sejarah artikel: & \\
Diterima $\quad:$ \\
Revisi $\quad:$ \\
Dipublikasikan $\quad:$ \\
\hline
\end{tabular}

\section{ABSTRAK}

Partisipasi masyarakat dalam politik yang mudah diukur intensitasnya adalah perilaku warga negara dalam Pemilu. Tingkat partisipasi Pemilu yang rendah merupakan tanda yang kurang baik karena pemerintah dianggap hanya melayani kepentingan beberapa kelompok. Komisi

Kata kunci:

Komisi Pemilihan Umum

Partisipasi Pemilih

Strategi Pemilihan Umum (KPU) sebagai lembaga penyelenggara Pemilu, berperan sebagai fasilitator antara calon dan pemilih berkewajiban untuk menjamin akses informasi serta kebutuhan informasi masyarakat, sehingga perlu memiliki strategi untuk meningkatkan partisipasi pemilih tersebut. Tujuan penelitian ini adalah untuk mengidentifikasi faktor-faktor lingkungan internal dan eksternal dalam meningkatkan partisipasi pemilih, memformulasikan alternatif-altrenatif startegi berdasarkan faktor internal dan eksternal serta menetapkan strategi yang dapat diimplementasikan oleh KPU Kabupaten Bogor. Metode penelitian menggunakan analisis matriks IFE, matriks EFE, matriks IE, SWOT dan QSPM sebagai tahap keputusan akhir. Penelitian menghasilkan strategi utama yang dapat diimplementasikan, yaitu menyusun keputusan-keputusan teknis penyelenggaraan pemilihan yang disesuaikan dengan keadaan di Kabupaten Bogor dengan tetap berpedoman pada peraturan perundangundangan di atasnya.

Keywords:

General Election Commission

Election Participation

Strategy

\begin{abstract}
Strategy of The General Election Commission (KPU) of Bogor Districts in Raising The Voters Participation on General Election 2019. The citizen's participation in politics that can be measurable is the citizen's behavior in the election. The low level of participation is considered as an unfavourable sign that the government only serves the interest of some groups. The General Election Commission (KPU) as the election conventions plays a critical role as the facilitator between the candidates and the voters, they have to ensure the access of information and all the society's information necessities. Therefore, it needs to have the right strategy in raising the voters participation. The purpose of this research is to identify factors of the internal and external environments in raising the voters participation, to formulate the alternative strategies based on the internal and external factors and to define the right strategy that can be implemented by The General Election Commission (KPU) of Bogor districts. The research methodology uses analysis of the IFE matrix, EFE matrix, IE matrix, SWOT and QSPM as the final decision the research resulting the main strategy that can be implemented, which is composing decisions the technique of election convention that is customized with Bogor district condition which based on the rules of regulations.
\end{abstract}

\section{Pendahuluan}

Pemilihan Umum (Pemilu) merupakan conditio sine quanon (syarat mutlak) bagi suatu negara demokrasi modern, artinya rakyat memilih seseorang untuk mewakilinya dalam rangka keikutsertaan rakyat dalam 
penyelenggaraan pemerintahan negara, sekaligus merupakan suatu rangkaian kegiatan politik untuk menampung kepentingan atau aspirasi masyarakat. Dalam konteks manusia sebagai individu warga negara, maka Pemilu berarti proses penyerahan sementara hak politiknya. Hak tersebut adalah hak berdaulat untuk turut serta menjalankan penyelenggaraan negara (Budiardjo 2010). Suatu bentuk partisipasi politik yang mudah diukur intensitasnya adalah perilaku warga negara dalam pemilihan umum, antara lain melalui perhitungan persentase orang menggunakan hak pilihnya (voter turnout) dibanding dengan jumlah seluruh warga negara yang berhak memilih (Verba dan Nie dalam Budiardjo, 2010).

Indonesia merupakan negara demokrasi yang menggunakan Pemilu sebagai sarana siklus pergantian pemimpinnya. Pasca reformasi, pada tahun 2004 masyarakat Indonesia dapat memilih partai politik beserta kandidatnya sebagai Anggota DPR, DPD, DPRD Provinsi dan DPRD Kabupaten/Kota serta Presiden dan Wakil Presiden secara langsung. Selain itu, dengan terbitnya Undang-Undang Nomor 32 Tahun 2004 diaturlah Penyelenggaraan Pemilihan Kepala Daerah dan Wakil Kepala Daerah (Pilkada) secara langsung. Penyelenggaraan Pemilu diselenggarakan oleh suatu komisi pemilihan umum yang bersifat nasional, tetap, dan mandiri (UUD 1945). Komisi Pemilihan Umum (KPU) berdiri secara hierarki, yaitu KPU sebagai lembaga penyelenggara tingkat nasional, KPU/KIP Provinsi penyelenggara tingkat provinsi serta KPU/KIP Kabupaten/Kota penyelenggara di tingkat kabupaten/kota.

Kabupaten Bogor merupakan kabupaten dengan jumlah pemilih terbesar di Provinsi Jawa Barat bahkan di tingkat nasional. Pelaksanaan Pemilu dan penyelenggaraan pemilihan kepala daerah di Kabupaten Bogor merupakan tugas dan wewenang KPU Kabupaten Bogor, yang salah satu kewajibannya adalah memutakhirkan data dan daftar pemilih serta menyelenggarakan sosialisasi penyelenggaraan Pemilu dan/atau yang berkaitan dengan tugas dan wewenang KPU Kabupaten Bogor kepada masyarakat. Sejak tahun 2004 hingga 2018 KPU Kabupaten Bogor telah melaksanakan dan menyelenggarakan beberapa periode Pemilu, Pemilihan Gubernur dan Wakil Gubernur Jawa Barat serta Bupati dan Wakil Bupati Bogor dengan tingkat partisipasi pemlih.
Tabel 1.Tingkat Partisipasi Pemilih

\begin{tabular}{|c|c|c|c|c|c|}
\hline No & $\begin{array}{l}\text { Jenis Pemilu/ } \\
\text { Pemilihan }\end{array}$ & $\begin{array}{l}\text { Tahun } \\
\text { Pemilu/ } \\
\text { Pemilihan }\end{array}$ & $\begin{array}{c}\text { Jumlah } \\
\text { Pemilih } \\
\text { Terdaf- } \\
\text { tar }\end{array}$ & $\begin{array}{c}\text { Penggu- } \\
\text { na Hak } \\
\text { Pilih }\end{array}$ & $\begin{array}{c}\text { Persentase } \\
\text { Pengguna } \\
\text { Hak Pilih }\end{array}$ \\
\hline 1. & $\begin{array}{l}\text { Pemilu DPR, } \\
\text { DPD, DPRD } \\
\text { Provinsi, } \\
\text { DPRD } \\
\text { Kabupaten/ } \\
\text { Kota }\end{array}$ & 2004 & 2.545 .479 & 2.127 .455 & $83,58 \%$ \\
\hline 2. & $\begin{array}{l}\text { Pemilu } \\
\text { Presiden dan } \\
\text { Wakil Presiden } \\
\text { (Putaran 1/P1) }\end{array}$ & 2004 & 2.586 .378 & 2.156 .763 & $83,39 \%$ \\
\hline 3. & $\begin{array}{l}\text { Pemilu } \\
\text { Presiden dan } \\
\text { Wakil Presiden } \\
\text { (Putaran 2/P2) }\end{array}$ & 2004 & 2.559 .953 & 2.088 .622 & $81,59 \%$ \\
\hline 4. & $\begin{array}{l}\text { Pemilihan } \\
\text { Gubernur dan } \\
\text { Wakil } \\
\text { Gubernur Jawa } \\
\text { Barat }\end{array}$ & 2008 & 2744303 & 1767501 & $64,41 \%$ \\
\hline 5. & $\begin{array}{l}\text { Pemilihan } \\
\text { Bupati dan } \\
\text { Wakil Bupati } \\
\text { Bogor } \\
\text { (Putaran } \\
\text { 1/P1) }\end{array}$ & 2008 & 2.800 .701 & 1.775 .009 & $63,38 \%$ \\
\hline 6. & $\begin{array}{l}\text { Pemilihan } \\
\text { Bupati dan } \\
\text { Wakil Bupati } \\
\text { Bogor (Putaran } \\
\text { 2/P2) }\end{array}$ & 2008 & 2.810 .462 & 1.634 .647 & $58,16 \%$ \\
\hline 7. & $\begin{array}{l}\text { Pemilu DPR, } \\
\text { DPD, DPRD } \\
\text { Provinsi, } \\
\text { DPRD } \\
\text { Kabupaten/ } \\
\text { Kota }\end{array}$ & 2009 & 2.860 .585 & 2.113 .904 & $73,90 \%$ \\
\hline 8. & $\begin{array}{l}\text { Pemilu } \\
\text { Presiden dan } \\
\text { Wakil } \\
\text { Presiden }\end{array}$ & 2009 & 3.023 .543 & 2.414 .409 & $79,85 \%$ \\
\hline 9. & $\begin{array}{l}\text { Pemilihan } \\
\text { Gubernur dan } \\
\text { Wakil } \\
\text { Gubernur Jawa } \\
\text { Barat }\end{array}$ & 2013 & 3340002 & 2086948 & $62,48 \%$ \\
\hline 10 & $\begin{array}{l}\text { Pemilihan } \\
\text { Bupati dan } \\
\text { Wakil Bupati } \\
\text { Bogor }\end{array}$ & 2013 & 3.190 .543 & 2.008 .165 & $62,94 \%$ \\
\hline 11 & $\begin{array}{l}\text { Pemilu DPR, } \\
\text { DPD, DPRD } \\
\text { Provinsi, } \\
\text { DPRD } \\
\text { Kabupaten/ } \\
\text { Kota } \\
\end{array}$ & 2014 & 3.231 .372 & 2.421 .667 & $74,94 \%$ \\
\hline 12 & $\begin{array}{l}\text { Pemilu } \\
\text { Presiden dan } \\
\text { Wakil Presiden }\end{array}$ & 2014 & 3.318 .924 & 2.527 .318 & $76,15 \%$ \\
\hline 13 & $\begin{array}{l}\text { Pemilihan } \\
\text { Gubernur dan } \\
\text { Wakil } \\
\text { Gubernur Jawa } \\
\text { Barat serta } \\
\text { Bupati dan } \\
\text { Wakil Bupati } \\
\text { Bogor } \\
\text { (Pemilihan } \\
\text { Serentak) }\end{array}$ & 2018 & 3.374 .610 & 2.358 .564 & $69,89 \%$ \\
\hline
\end{tabular}


Gambar 1. Tingkat partisipasi pemilih

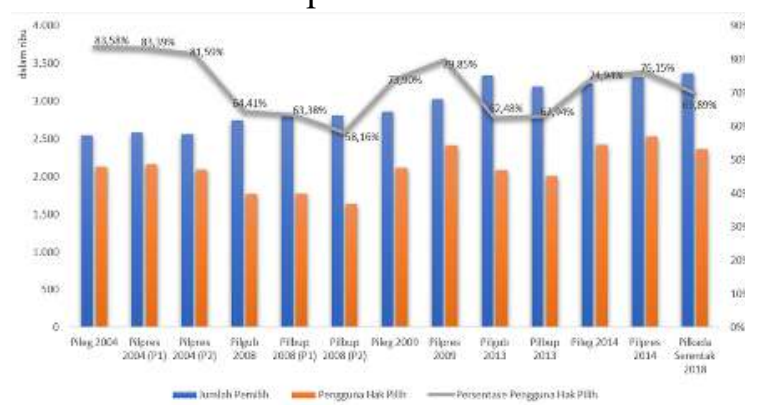

Tingkat partisipasi pada pemilihan terakhir, yaitu Pemilihan Serentak Gubernur dan Wakil Gubernur Jawa Barat serta Bupati dan Wakil Bupati Bogor Tahun 2018, menurun sekitar tujuh persen dibandingkan dua Pemilu sebelumnya pada tahun 2014, jika dibandingkan dengan pemilihan sejenis, tingkat partisipasi pemilih tahun 2018 cenderung meningkat, tetapi masih lebih rendah dari target nasional serta proyeksi KPU Kabupaten Bogor yang disusun pada masa persiapan pemilihan. Berdasarkan Renstra KPU Tahun 2015-2019 partisipasi pemilih seharusnya dapat mencapai $77,5 \%$, dan menurut target KPU Kabupaten Bogor tingkat partisipasi pemilih dapat mencapai $78 \%$.

Gambar 2. Tingkat partisipasi pemilih Pemilihan Tahun 2018 terhadap targetnya

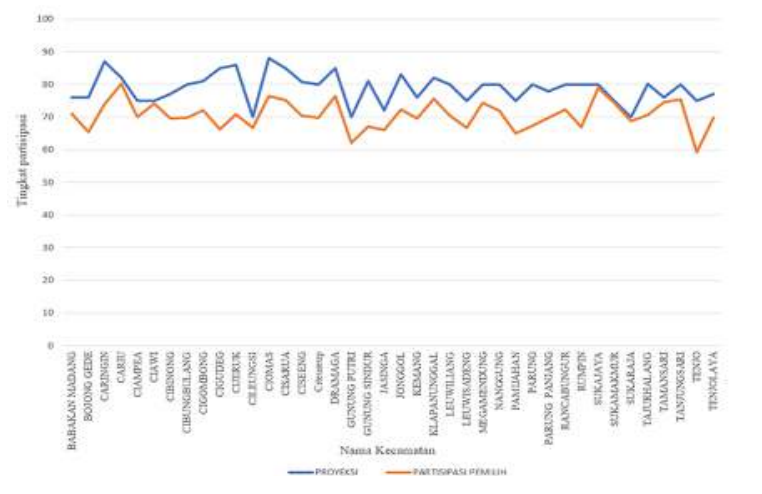

Tingkat partisipasi masyarakat yang rendah dapat dianggap sebagai tanda yang kurang baik, karena ditafsirkan banyak warga tidak menaruh perhatian terhadap masalah kenegaraan dan adanya penilaian bahwa pemerintah hanya melayani kepentingan beberapa kelompok akibat pemerintah yang kurang tanggap karena pendapat (suara) masyarakat yang tidak dikemukakan (Budiardjo 2010). Pemilu maupun pemilihan merupakan ruang dialektika antara masyarakat dengan calon pemimpinnya, proses dimana para calon pemimpin memberikan visi, misi dan program serta masyarakat yang hendak menyampaikan harapan yang ingin diwujudkan dan penyelesaian terhadap permasalahannya. KPU harus dapat menjadi fasilitator dan menyederhanakan proses dialektika tersebut, menjamin akses informasi serta kebutuhan informasi masyarakat agar masyarakat terbangun kesadarannya untuk mau menggunakan hak pilihnya melalui Pemilu (Kurniawan dan Haikal, 2016).

KPU Kabupaten Bogor sebagai pelaksana dan penyelenggara Pemilu di Kabupaten Bogor juga memiliki peranan tersebut, menjadi fasilitator dan menjamin akses informasi agar masyarakat Kabupaten Bogor memiliki kesadaran untuk menggunakan hak pilihnya sehingga target tingkat partisipasi pemilih dapat tercapai, baik dari segi kuantitas maupun kualitas. Terlebih lagi, setelah pelaksanaan pemilihan serentak tahun 2018 ini, masyarakat Indonesia termasuk masyarakat Kabupaten Bogor akan menghadapi Pemilu Anggota DPR, DPD, DPRD Provinsi, DPRD Kabupaten/Kota sekaligus Pemilu Presiden dan Wakil Presiden Tahun 2019 yang akan diselenggarakan pada hari yang sama. Pemilu ini sangat penting, selain sebagai siklus pergantian pemimpin, tingkat partisipasi Pemilu yang tinggi dapat menjamin legitimasi pemerintahan yang kuat karena masyarakat turut serta secara langsung dalam menentukan para pemimpinnya di perlemen serta presiden sebagai kepala negara. Oleh karena itu, KPU Kabupaten Bogor perlu memiliki strategi untuk dapat meningkatkan partisipasi pemilih pada Pemilu 2019, dengan menganalisis keadaan lingkungan internal dan eksternal saat pemilihan Bupati dan Wakil Bupati Bogor 2018 sebagai pelaksanaan program kegiatan yang berkesinambungan.

Rumusan masalah penelitian ini adalah: (1) Apa saja yang menjadi faktor lingkungan internal dan eksternal pada pemilihan Bupati dan Wakil Bupati Bogor Tahun 2018 yang dapat menjadi upaya dalam meningkatkan partisipasi Pemilu 2019 ? (2) Bagaimana memformulasikan alternatif strategi yang dapat diterapkan oleh KPU Kabupaten Bogor untuk meningkatkan partisipasi pemilih berdasarkan faktor lingkungan internal-eksternal tersebut? (3) Bagaimana strategi yang dapat diimplementasikan oleh KPU Kabupaten Bogor untuk meningkatkan partisipasi pemilih pada Pemilu Tahun 2019? Penelitian ini bertujuan untuk: (1) Mengidentifikasi faktorfaktor lingkungan internal dan eksternal pada Pemilihan Bupati dan Wakil Bupati Bogor Tahun 
2018 yang dapat menjadi upaya dalam meningkatkan partisipasi Pemilih Tahun 2019; (2) Memformulasikan alternatif-alternatif strategi berdasarkan faktor internal dan eksternal yang sesuai agar dapat meningkatkan partisipasi pemilih; (3) Menetapkan strategi yang dapat diimplementasikan oleh KPU Kabupaten Bogor untuk meningkatkan partisipasi pemilih pada Pemilu Tahun 2019.

\section{Metode}

Metode penelitian Strategi KPU Kabupaten Bogor dalam Meningkatkan Partisipasi Pemilih pada Pemilihan Umum Tahun 2019 sebagaimana dapat dilihat pada Gambar 3.

Gambar 3. Kerangka Pemikiran

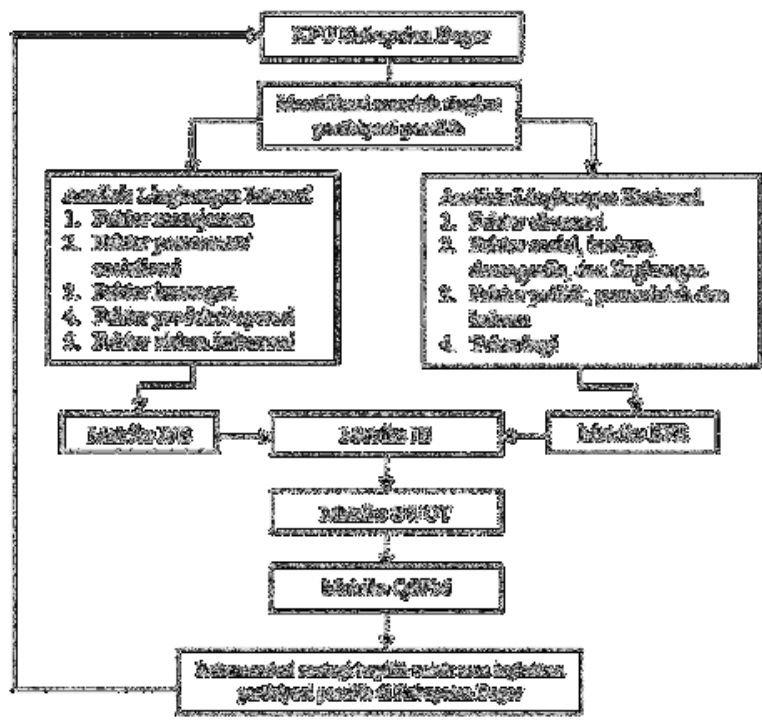

Penelitian dilakukan di Kantor Komisi Pemilihan Umum Kabupaten Bogor yang beralamat di Jalan Tegar Beriman No. 35 Kelurahan Tengah Kecamatan Cibinong Kabupaten Bogor. Waktu penelitian dilakukan mulai Agustus hingga September 2018. Sampel pada penelitian ini dipilih dengan menggunakan metode nonprobability sampling dengan pertimbangan tertentu (purposive sampling) sehingga memerlukan kriteria khusus agar sampel sesuai dengan tujuan penelitian dan dapat memberikan nilai yang lebih representatif. Jenis data dalam penelitian ini meliputi data kualitatif dan kuantitatif dengan sumber data yang digunakan adalah data primer diperoleh langsung melalui observasi, wawancara dan kuesioner yang diisi oleh sampel yaitu, Komisioner KPU Kabupaten Bogor dan Anggota Bawaslu Kabupaten Bogor dan sumber sekunder diperoleh melalui literatur ataupun studi pustaka yang bersumber dari buku, data laporan internal KPU Kabupaten Bogor, jurnal, skripsi, dan situs internet Pemda Bogor, KPU, BPS, tribunnews, freddyrangkuti.wordpress.com, dan statistikian. com. Metode pengolahan dan analisis data dilakukan dalam tiga tahap, yaitu: (1) tahap pengumpulan data (input stage) dengan menganalisis faktor lingkungan internal dan eksternal melalui matriks IFE dan EFE; (2) tahap pencocokan (matching stage) dengan mariks IE dan SWOT; (3) tahap pengambilan keputusan (decision stage) dengan matriks perencanaan strategi kuantitatif (Quantitative Strategic Planning Matrix atau QSPM).

\section{Hasil dan pembahasan}

Tahap pertama adalah dengan melakukan identifikasi terhadap faktor lingkungan, yang meliputi lingkungan internal dan eksternal. Identifikasi faktor lingkungan internal, dimaksudkan untuk menganalisis faktor-faktor yang menjadi kekuatan (strength) dan kelemahan (weakness) yang dimiliki KPU Kabupaten Bogor dalam rangka peningkatan partisipasi pemilih Pemilu 2019 yang meliputi aspek manajemen, pemasaran/sosialisasi, keuangan, produksi/ operasi. Sedangkan, tahap identifikasi lingkungan eksternal berfokus pada kejadian di luar kendali organisasi yang dapat menjadi peluang (opportunity) serta ancaman (treat) dengan tujuan mengembangkan sejumlah kesempatan yang dapat dimanfaatkan oleh organisasi dan ancaman yang sebaiknya dihindari. Faktor eksternal yang diidentifikasi pada KPU Kabupaten Bogor meliputi faktor ekonomi, faktor sosial, budaya, demografi dan lingkungan, kekuatan politik, pemerintah, dan hukum, serta faktor kekuatan teknologi. Faktor ini dapat menjadi input yang terukur dalam perumusan strategi dengan menentukan skor untuk setiap faktor kekuatankelemahan serta peluang-ancaman. Skor diperoleh dari hasil perkalian nilai bobot dengan rataan rating dalam matriks IFE dan EFE sebagaimana terdapat pada Tabel 2 dan Tabel 3. 
Triana Pertiwi, Siti Rahmawati Strategi KPU Kabupaten Bogor.....

Tabel 2. Perhitungan skor kekuatan pada Matriks IFE

\begin{tabular}{|c|c|c|c|c|}
\hline Kode & Faktor Internal & $\begin{array}{l}\text { Nilai } \\
\text { Bobot }\end{array}$ & $\begin{array}{c}\text { Rataan } \\
\text { Rating }\end{array}$ & Skor \\
\hline S1 & $\begin{array}{lr}\text { Penyusunan program } \\
\text { dan anggaran } & \begin{array}{r}\text { sudah } \\
\text { dasar }\end{array} \\
\text { memiliki } & \text { peraturan yang berlaku } \\
\text { secara nasional } & \end{array}$ & 0,061 & 3,8 & 0,234 \\
\hline $\mathrm{S} 2$ & $\begin{array}{l}\text { Mengadopsi rancangan } \\
\text { anggaran serta program } \\
\text { kegiatan pada pemilihan } \\
\text { sebelumnya menghemat } \\
\text { waktu perencanaan }\end{array}$ & 0,045 & 3 & 0,136 \\
\hline $\mathrm{S} 3$ & 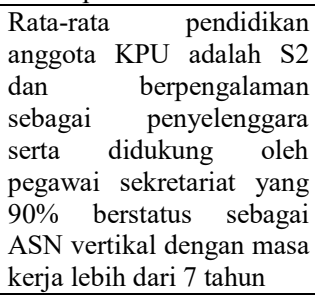 & 0,045 & 3,2 & 0,145 \\
\hline S4 & $\begin{array}{l}\text { Adanya KAK dan SOP } \\
\text { untuk pelaksanaan } \\
\text { program kegiatan }\end{array}$ & 0,055 & 3,4 & 0,187 \\
\hline S5 & 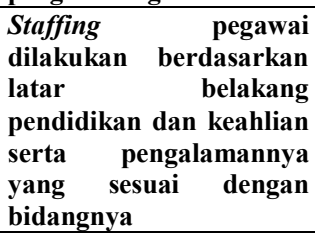 & 0,055 & 3,4 & 0,187 \\
\hline S6 & $\begin{array}{l}\text { Pegawai dapat } \\
\text { memberikan masukan atau } \\
\text { pendapat saat rapat dengan } \\
\text { putusan tertinggi tetap } \\
\text { pada kesepakatan anggota } \\
\text { KPU melalui Rapat Pleno }\end{array}$ & 0,051 & 3,2 & 0,166 \\
\hline S7 & 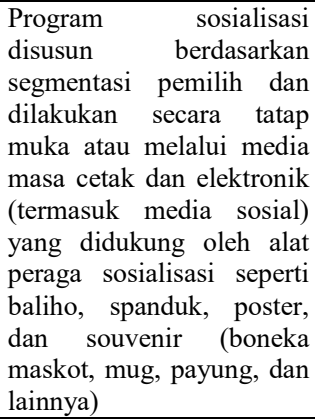 & 0,058 & 3,2 & 0,186 \\
\hline S8 & $\begin{array}{l}\text { Sumber dana berasal } \\
\text { dari dana hibah yang } \\
\text { besarannya } \\
\text { dengan sesuai } \\
\text { kegiatan yang diajukan } \\
\text { KPU dalam RAB }\end{array}$ & 0,055 & 3,4 & 0,187 \\
\hline S9 & $\begin{array}{lr}\text { Pelayanan } & \text { pemberian } \\
\text { informasi } & \text { pemilihan } \\
\text { kepada masyarakat dengan } \\
\text { sistem 1 pintu melalui } \\
\text { PPID }\end{array}$ & 0,058 & 3,2 & 0,186 \\
\hline \multirow[t]{2}{*}{$\mathrm{S} 10$} & $\begin{array}{lr}\text { Penggunaan } & \text { sistem } \\
\text { informasi berbasis aplikasi } \\
\text { (seperti: Silon, Situng, } \\
\text { Sidalih) mempermudah } \\
\text { KPU dalam mengolah, } \\
\text { menampilkan serta } \\
\text { melaporkan data kegiatan }\end{array}$ & 0,052 & 3 & 0,155 \\
\hline & Total & & & 1,769 \\
\hline
\end{tabular}

Tabel 3. Perhitungan skor kelemahan pada Matriks IFE

\begin{tabular}{|c|c|c|c|c|}
\hline Kode & Faktor Internal & $\begin{array}{l}\text { Nilai } \\
\text { Bobot }\end{array}$ & $\begin{array}{l}\text { Rataan } \\
\text { Rating }\end{array}$ & Skor \\
\hline W1 & $\begin{array}{l}\text { Kurangnya inovasi } \\
\text { program kegiatan yang } \\
\text { disusun dalam perencanaan } \\
\text { karena keterbatasan waktu } \\
\text { penyusunan sehingga } \\
\text { mengadopsi program pada } \\
\text { pemilihan sebelumnya }\end{array}$ & 0,048 & 2,2 & 0,107 \\
\hline W2 & $\begin{array}{lr}\text { Keterbatasan } & \text { jumlah } \\
\text { SDM } & \text { untuk } \\
\text { melaksanakan } & \text { program } \\
\text { dan jadwal } & \text { Pilkada } \\
\text { serentak yang juga } & \text { juak } \\
\text { berhimpitan dengan } & \\
\text { tahapan Pemilu 2019 }\end{array}$ & $\mathbf{0 , 0 5 5}$ & 2,2 & 0,121 \\
\hline W3 & $\begin{array}{l}\text { Tenaga pendukung rata-rata } \\
\text { fresh graduate dengan } \\
\text { minimnya pengalaman } \\
\text { sebagai penyelenggara }\end{array}$ & 0,038 & 2 & 0,077 \\
\hline W4 & $\begin{array}{lr}\text { Pengambilan } & \text { keputusan } \\
\text { yang kadang } & \text { tertunda } \\
\text { karena syarat jumlah } \\
\text { minimal anggota untuk } \\
\text { rapat pleno dan mengambil } \\
\text { keputusan tidak terpenuhi }\end{array}$ & 0,045 & 1,8 & 0,081 \\
\hline W5 & $\begin{array}{lr}\text { Keadaan } & \text { lingkungan } \\
\text { internal yang } \begin{array}{r}\text { tidak } \\
\text { kondusif }\end{array} \\
\text { komunikasi yang kurang } \\
\text { efektif antara staf dengan } \\
\text { atasan serta rendahnya } \\
\text { motivasi }\end{array}$ & $\mathbf{0 , 0 5 8}$ & 2,4 & 0,139 \\
\hline W6 & $\begin{array}{l}\text { Tidak meratanya kewajiban } \\
\text { penggunaan KAK dan SOP } \\
\text { sebagai dasar pelaksanaan } \\
\text { teknis kegiatan untuk } \\
\text { semua bidang }\end{array}$ & 0,0517 & 2 & 0,103 \\
\hline W7 & $\begin{array}{l}\text { Kegiatan sosilalisasi tatap } \\
\text { muka masih tersentral di } \\
\text { ibu kota kabupaten dengan } \\
\text { jumlah peserta yang } \\
\text { terbatas }\end{array}$ & 0,0517 & 2 & 0,103 \\
\hline W8 & $\begin{array}{l}\text { Pelayanan PPID yang } \\
\text { masih lambat karena } \\
\text { birokrasi } \\
\text { formulir yang wajib diisi) } \\
\text { serta ketersediaan data } \\
\text { yang tidak tersimpan rapi } \\
\text { dan sistematis }\end{array}$ & 0,055 & 2,2 & 0,121 \\
\hline W9 & $\begin{array}{lr}\text { Penggunaan } & \text { sistem } \\
\text { informasi yang } & \text { sering } \\
\text { terkendala } & \text { proses } \\
\text { maintenance } & \text { dari } \\
\text { pengelola pusat } & \\
\end{array}$ & $\mathbf{0 , 0 5 8}$ & 2,2 & 0,128 \\
\hline & Total & & & 0,983 \\
\hline \multicolumn{4}{|c|}{$\begin{array}{c}\text { Total Matriks IFE (Kekuatan \& } \\
\text { Kelemahan) }\end{array}$} & 2,752 \\
\hline
\end{tabular}

Hasil penghitungan matriks IFE menunjukan total skor faktor strategis internal sebagai kekuatan adalah 1,769 dan total skor kelemahan sebesar 0,983. Hal ini menunjukan bahwa KPU Kabupaten Bogor memiliki kekuatan yang lebih dibanding kelemahannya serta total nilai matriks IFE 2,752 $(>2,5)$ juga menunjukan bahwa KPU Kabupaten Bogor secara internal 
berada di posisi yang baik. Kekuatan utama terdapat pada penyusunan program dan anggaran sudah memiliki dasar peraturan yang berlaku secara nasional dengan skor 0,234. Peraturan yang berlaku secara nasional mempermudah KPU Kabupaten Bogor dalam menyusun setiap program kegiatan pelaksanaan tahapan serta anggaran, kuatnya dasar hukum, serta keseragaman dasar pemberlakuan anggaran melalui PMK (Peraturan Menteri Keuangan). Kekuatan berikutnya dengan skor 0,187 adalah adanya KAK dan SOP untuk pelaksanaan program kegiatan, staffing pegawai dilakukan berdasarkan latar belakang pendidikan dan keahlian serta pengalamannya yang sesuai dengan bidangnya, dan sumber dana berasal dari dana hibah yang besarannya sesuai dengan program kegiatan yang diajukan KPU dalam RAB. KAK dan SOP disusun sebagai dasar teknis pelaksanaan kegiatan tahapan sehingga pelaksanaannya lebih terkontrol.

Faktor yang menjadi kelemahan utama adalah keadaan lingkungan internal yang tidak kondusif karena komunikasi yang kurang efektif antara staf dengan atasan serta rendahnya motivasi dengan skor 0,139. Pelaksanaan kegiatan tahapan yang padat dan saling berhimpitan serta berbatas waktu seharusnya diperkuat dengan koordinasi yang baik terutama di lingkungan intern KPU Kabupaten Bogor itu sendiri. Tetapi hal tersebut belum sepenuhnya dapat dilakukan, baik dalam hubungan vertikal (atasan-bawahan) maupun horizontal (antar pimpinan/antar staf pelaksana). Seperti misalnya, rapat persiapan pelaksanaan atau evaluasi program kegiatan yang tidak dihadiri oleh pejabat dan/atau staf pelaksana terkait, mengalami deadlock sehingga rapat dapat dilakukan berulang-ulang untuk membahas hal yang sama, pembahasan suatu masalah melalui media komunikasi sosial (whatsapp) bukan duduk bersama dan berdiskusi secara langsung (tatap muka), instruksi yang timpang tindih, perlakuan pimpinan yang berbeda terhadap subbagian satu dengan subbagian lain, serta kurangnya pengakuan atas kerja dan upaya staf pelaksana dalam melakukan pekerjaan. Faktor kelemahan berikutnya adalah penggunaan sistem informasi yang sering terkendala proses maintenance dari pengelola pusat dengan skor 0,128. Sistem informasi yang berbasis online memerlukan proses maintenance yang terkadang memakan waktu cukup lama, sedangkan output dari sistem informasi yang digunakan ini adalah sebagai salah satu instrumen pengambilan keputusan (penyajian data sesuai dengan formulir dalam Peraturan KPU) sehingga perlu dibuat kembali output yang sama dengan cara manual disamping tahapan dalam sistem informasi yang tetap harus dilaksanakan, karena digunakan sebagai sarana monitoring KPU RI dan KPU Provinsi atas kegiatan KPU Kabupaten/Kota penyelenggara Pilkada serta sumber informasi masyarakat. Keterbatasan jumlah SDM untuk melaksanakan program dan jadwal Pilkada serentak yang juga berhimpitan dengan tahapan Pemilu 2019 dan pelayanan PPID yang masih lambat karena birokrasi (banyak formulir yang wajib diisi) serta ketersediaan data yang tidak tersimpan rapi dan sistematis merupakan faktor kelemahan lainnya dengan skor 0,121 .

Identifikasi selanjutnya adalah terhadap lingkungan eksternal KPU Kabupaten Bogor yang dituangkan dalam matrik EFE yang menunjukkan peluang (opportunity) serta ancaman (treat) sebagaimana tabel 4 dan 5 .

Tabel 4. Perhitungan skor peluang pada Matriks EFE

\begin{tabular}{lllll}
\hline Kode & \multicolumn{1}{c}{ Faktor Eksternal } & $\begin{array}{c}\text { Nilai } \\
\text { Bobot }\end{array}$ & $\begin{array}{c}\text { Rataan } \\
\text { Rating }\end{array}$ & Skor \\
\hline O1 & Antusiasme pemilih pemula & 0,054 & 3,2 & 0,172 \\
\hline O2 & $\begin{array}{l}\text { Partisipasi pemilih perem- } \\
\text { puan yang semakin baik }\end{array}$ & 0,057 & 3,2 & 0,182 \\
\hline \multicolumn{6}{c}{$\begin{array}{l}\text { Masyarakat urban yang } \\
\text { memiliki pemikiran terbuka } \\
\text { terhadap kehidupan bernegara }\end{array}$} & 0,051 & 3 & 0,152 \\
terutama termasuk penggunaan \\
haknya suaranya
\end{tabular}


Tabel 5. Perhitungan skor ancaman pada Matriks EFE

\begin{tabular}{|c|c|c|c|c|}
\hline Kode & Faktor Eksternal & $\begin{array}{l}\text { Nilai } \\
\text { Bobot }\end{array}$ & $\begin{array}{c}\text { Rataan } \\
\text { Rating }\end{array}$ & Skor \\
\hline $\mathrm{T} 1$ & $\begin{array}{l}\text { Tingkat kesibukan dan } \\
\text { pertimbangan untung-rugi } \\
\text { masyarakat akan persepsi } \\
\text { bahwa ber-partisipasi } \\
\text { dalam pe-milihan tidak } \\
\text { memberi keuntungan apa- } \\
\text { apa }\end{array}$ & 0,051 & 3 & 0,152 \\
\hline $\mathrm{T} 2$ & $\begin{array}{l}\text { Laju pertumbuhan dan } \\
\text { perpindahan yang tinggi } \\
\text { membuat jumlah pemilih } \\
\text { sangat dinamis }\end{array}$ & 0,053 & 3,2 & 0,172 \\
\hline T3 & $\begin{array}{l}\text { Kesenjangan sosial di } \\
\text { lingkungan masyarakat } \\
\text { yang menimbulkan apatis } \\
\text { satu golongan tertentu }\end{array}$ & 0,044 & 2,4 & 0,106 \\
\hline $\mathrm{T} 4$ & 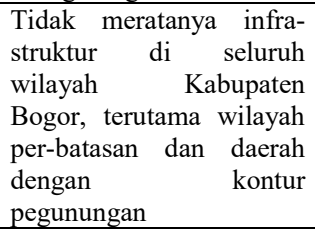 & 0,050 & 3 & 0,152 \\
\hline $\mathrm{T} 5$ & $\begin{array}{l}\text { Kekhawatiran akan } \\
\text { maraknya organisasi yang } \\
\text { tumbuh akan di- } \\
\text { manfaatkan oleh pihak } \\
\text { yang tidak bertang-gung } \\
\text { jawab sebagai alat politik } \\
\text { untuk menghambat } \\
\text { jalannya proses pemilihan }\end{array}$ & 0,037 & 2,6 & 0,099 \\
\hline T6 & $\begin{array}{lr}\text { Prioritas masyarakat akan } \\
\text { tradisi } & \text { dibanding } \\
\text { mengurusi } & \text { kehidupan } \\
\text { bernegara } & \text { (seperti: lebih } \\
\text { memilih } & \text { berlibur } \\
\text { dibanding pergi ke TPS) }\end{array}$ & 0,047 & 2,6 & 0,123 \\
\hline T7 & $\begin{array}{l}\text { Juknis dan Surat } \\
\text { Edaran yang di- } \\
\text { keluarkan oleh KPU RI } \\
\text { dan KPU Provinsi } \\
\text { sering berbatas dengan } \\
\text { waktu akhir tahapan }\end{array}$ & $\mathbf{0 , 0 5 7}$ & 3,4 & 0,194 \\
\hline T8 & $\begin{array}{l}\text { Perubahan peraturan } \\
\text { dan penerbitan kebi- } \\
\text { jakan atas peraturan/ } \\
\text { keputusan sebelumnya } \\
\text { dapat dinilai sebagai } \\
\text { lemahnya konsistensi } \\
\text { ketegasan hukum } \\
\text { pelaksanaan pemilihan }\end{array}$ & $\mathbf{0 , 0 5 7}$ & 3,8 & 0,216 \\
\hline T9 & 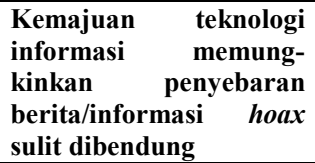 & 0,057 & 3,6 & 0,205 \\
\hline $\mathrm{T} 10$ & $\begin{array}{l}\text { Teknologi } \text { berbasis } \\
\text { aplikasi yang memu- } \\
\text { dahkan pekerjaan akan } \\
\text { menimbulkan tergan- } \\
\text { tungan serta menurunkan } \\
\text { pemahaman mengenai } \\
\text { tahapan pengolahan data } \\
\text { secara manual }\end{array}$ & 0.051 & 3 & 0,152 \\
\hline & \multicolumn{3}{|l|}{ Total } & 1,571 \\
\hline & \multicolumn{3}{|c|}{$\begin{array}{c}\text { Total Matriks EFE (Peluang dan } \\
\text { Ancaman) }\end{array}$} & 3,231 \\
\hline
\end{tabular}

Hasil penghitungan matriks EFE menunjukan total skor faktor strategis eksternal sebagai peluang adalah 1,659 dan total skor ancaman sebesar 1,571. Hal ini menunjukan bahwa KPU Kabupaten Bogor memiliki peluang yang lebih baik untuk mengurangi ancaman yang ada di lingkungan eksternal. Total nilai matriks EFE adalah 3,231 $(>2,5)$ juga menunjukan bahwa KPU Kabupaten Bogor secara eksternal berada di posisi yang baik.

Peluang utama dari analisis lingkungan eksternal, yaitu pelaksanaan pemilihan dijamin dan diatur oleh undang-undang dan peraturan lainnya dengan skor 0,216 . Faktor ini menjadi peluang karena dapat menambah kepercayaan masyarakat bahwa pelaksanaan pemilihan memiliki kepastian hukum. Peraturan perundangundangan juga menjamin hak dan kewajiban penyelenggara, peserta, serta pemilih, sehingga pelaksanaan setiap kegiatan dapat terukur (akuntabel), adil dan proporsional. Hal ini membuka peluang bagi masyarakat untuk menggunakan hak pilihnya dalam pemilihan. Faktor peluang kedua dengan skor 0,205 adalah teknologi informasi membantu penyebaran informasi secara cepat dengan jangkauan yang luas. Teknologi informasi berupa media sosial dapat menyebarkan informasi tentang pemilihan dalam waktu yang singkat kepada berbagai lapisan masyarakat sehingga sangat terbuka peluang masyarakat mendapat informasi yang cukup untuk dapat menggunakan hak pilihnya. Koordinasi yang baik antara KPU Kabupaten Bogor dengan Pemerintah Daerah beserta jajaran Muspida lainnya adalah faktor peluang terbesar ketiga dengan skor 0,194. Pelaksanaan pemilihan merupakan tanggung jawab KPU sebagai penyelenggara, tetapi pada pelaksanaanya KPU tidak dapat berdiri sendiri, dukungan pemerintah daerah dan jajaran muspida lainnya sangat dibutuhkan. Pemerintah daerah sangat mendukung dalam penyediaan dana, gedung dan fasilitas lainnya, melakukan kegiatan pendukung program-program KPU, membantu KPU bersinergi dan berkoordinasi dengan dinas-dinas terkait, pemerintah tingkat kecamatan hingga desa/kelurahan. Jajaran muspida seperti kepolisian menjamin keamanan selama pelaksanaan tahapan pemilihan, kejaksaan dan pengadilan memberikan pendampingan hukum sebagai langkah preventif dalam penanganan masalah pemilihan. Senergi yang baik antara KPU Kabupaten Bogor, Pemerintah Daerah serta jajaran Muspida lainnya dapat menjamin pelaksanaan pemilihan yang kondusif. 
Faktor yang menjadi ancaman utama yaitu perubahan peraturan dan penerbitan kebijakan atas peraturan/keputusan sebelumnya dapat dinilai sebagai lemahnya konsistensi ketegasan hukum pelaksanaan pemilihan dengan skor 0 , 216. Selama pelaksanaan pemilihan, dasar hukum terutama Peraturan KPU sering mengalami perubahan, baik penambahan ataupun penghapusan atas suatu pernyataan peraturan. Faktor ancaman berikutnya dengan skor 0,205 adalah kemajuan teknologi informasi yang memungkinkan penyebaran berita/informasi hoax sulit dibendung, hal ini mengakibatkan masyarakat menerima informasi yang salah dan dan membentuk persepsi yang ambigu mengenai berita/informasi tentang pemilihan, misalnya berita hoax mengenai kurangnya surat suara di beberapa TPS yang tersebar melalui broadcast media sosial sehingga banyak masyarakat yang akhirnya mengurungkan niat memberikan suara di TPS pada hari pencoblosan. Ancaman selanjutnya dengan skor 0,194 adalah juknis dan surat edaran yang dikeluarkan oleh KPU RI dan KPU Provinsi sering berbatas dengan waktu akhir tahapan, seperti syarat pendaftaran rekrutmen panitia adhoc yang tidak dapat mendaftarkan diri kembali jika sudah dua periode dalam jabatan yang sama. Hal ini mengakibatkan menurunnya jumlah pendaftar dan tidak mencukupinya quota pendaftaran. KPU RI dan KPU Provinsi menerbitkan surat edaran untuk menerangakan kebijakan atas syarat tersebut, tetapi surat edaran itu belum dapat tersampaikan secara luas kepada masyarakat karena berbatas waktu dengan jadwal penutupan rekrutmen panitia adhoc itu sendiri.

Hasil analisis matriks IFE dengan nilai 2,75 dan EFE dengan nilai 3,23, menunjukan posisi KPU Kabupaten Bogor sebagai organisasi untuk menyusun bentuk strategi yang sesuai dengan keadaan lingkungan internal dan eksternalnya melalui matrik IE.

Gambar 4. Analisis matriks IE

Rerdacarkan matrike IF KPI Kahunaten Skor Tertimbang Total IFE

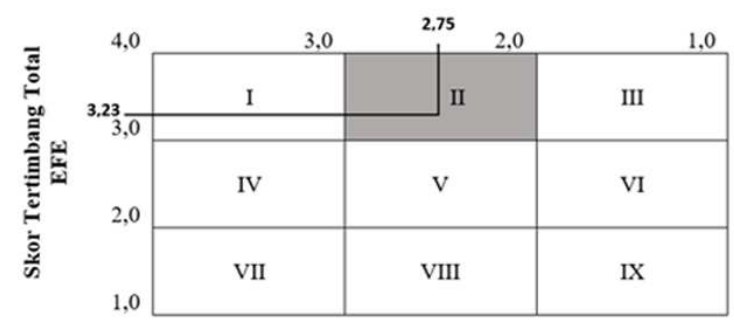

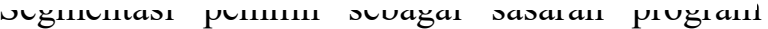
dapat diperluas sebagai bentuk pengembangan pasar serta sarana penyampaian informasi dan sosialisasi dikemas lebih menarik yang disesuaikan dengan sasarannya. Sedangkan strategi integratif yang dapat dilakukan yaitu integrasi ke depan (forward integration), integrasi ke belakang (backward integration). Integrasi ke depan dijalankan untuk meraih kendali atas alur penyampaian informasi dari atas hingga alur terbawah. Hal ini dapat dilakukan dengan menciptakan agen-agen sosialisasi. Integrasi ke belakang dilakukan untuk memperoleh kewenangan dan meningkatkan kendali yang dapat dilakukan dengan cara mempersiapkan prosedur atau standar pelaksanaan kegiatan yang akan digunakan oleh agen-agen sosialisasi dalam menyampaikan informasi kepada masyarakat.

Tahap kedua adalah formulasi alternatif strategi berdasarkan analisi posisi KPU Kabupaten Bogor. Tahap ini menggunakan matriks SWOT.

Gambar 5. Analisis matriks IE

\begin{tabular}{|c|c|c|}
\hline Faktor Eksternal & $\begin{array}{l}\quad \text { Kekuatan (Strength) } \\
\text { S1, S2, S3, S4, S5, S6, S7, S8, S9, } \\
\text { S10 }\end{array}$ & $\begin{array}{l}\text { Kelemahan (Weakness) } \\
\text { w1, w2, w3, w4, w5, w6, w7, } \\
\text { w8, w9 }\end{array}$ \\
\hline \multirow{2}{*}{$\begin{array}{l}\text { Peluang (Opportunity) } \\
\mathrm{O} 1, \mathrm{O} 2, \mathrm{O} 3, \mathrm{O} 4, \mathrm{O} 5, \mathrm{O} 6 \text {, } \\
\mathrm{O} 7, \mathrm{O} 8, \mathrm{O} 9\end{array}$} & Strategi SO & Strategi WO \\
\hline & $\begin{array}{l}\text { 1. Menyusun keputusan-keputusan } \\
\text { teknis penyelenggaraan } \\
\text { pemilihan yang disesuaikan } \\
\text { dengan keadaan di Kabupaten } \\
\text { Bogor dengan tetap perpedoman } \\
\text { pada peraturan perundang- } \\
\text { undangan di atasnya } \\
\text { 2. Menyusun program-program } \\
\text { penyampaian informasi dan } \\
\text { sosialisasi yang lebih inovatif } \\
\text { dengan memanfaatkan } \\
\text { keberadaan komunitas dan } \\
\text { organisasi masyarakat sebagai } \\
\text { agen sosialisasi }\end{array}$ & $\begin{array}{l}\text { 1. Meningkatkan sinergi di } \\
\text { lingkungan internal serta } \\
\text { mengintensifkan koordinasi } \\
\text { dengan pemerintah daerah dan } \\
\text { jajaran muspida lainnya } \\
\text { 2. Memanfaatkan teknologi } \\
\text { informasi dalam menyebarkan } \\
\text { informasi dan sarana } \\
\text { sosialisasi sebagai salah satu } \\
\text { alternatif efisiensi waktu dan } \\
\text { keterbatasan personil }\end{array}$ \\
\hline \multirow{2}{*}{$\begin{array}{l}\text { Threats (Ancaman) } \\
\text { T1, T2, T3, T4, T5, T,6, } \\
\text { T7, T8, T9, T10 }\end{array}$} & Strategi ST & Strategi $W T$ \\
\hline & $\begin{array}{l}\text { 1. Meningkatkan pelayanan } \\
\text { pemberian informasi kepada } \\
\text { masyarakat tentang Pemilu di } \\
\text { Kabupaten Bogor melalui PPID } \\
\text { 2. Memperbanyak kegiatan } \\
\text { sosialisasi secara tatap muka di } \\
\text { berbagai wilayah di Kabupaten } \\
\text { Bogor untuk menekan } \\
\text { penyebaran berita hoca melalui } \\
\text { teknologi informasi }\end{array}$ & $\begin{array}{l}\text { 1. Melakukan kajian-kajian atas } \\
\text { masalah yang diperkirakan } \\
\text { akan timbul dari persepsi yang } \\
\text { berbeda atas isi peraturan } \\
\text { perundang-undangan untuk } \\
\text { mendapatkan solusi awal } \\
\text { 2. Melakukan monitoring dan } \\
\text { evaluasi atas kegiatan } \\
\text { penyebaran informasi dan } \\
\text { sosialisasi }\end{array}$ \\
\hline
\end{tabular}

Strategi SO menggunakan kekuatan internal untuk mengambil keuntungan dari kesempatan eksternal. Strategi WO bertujuan untuk mengurangi kelemahan dengan mengambil keuntungan dari kesempatan eksternal. Strategi ST menggunakan kekuatan untuk menghindari atau mengurangi dampak ancaman eksternal. Strategi WT dilakukan sebagai taktik difensif yang dilakukan untuk mengurangi kelemahan internal dan menghindari ancaman eksternal. 
Triana Pertiwi, Siti Rahmawati $\mid$ Strategi KPU Kabupaten Bogor.....

Tahap ketiga adalah tahap keputusan penetapan strategi yang merupakan tahap penentuan strategi yang dinilai paling sesuai untuk diterapkan oleh KPU Kabupaten Bogor berdasarkan hasil analisis tahap pencocokan pada matriks SWOT. Instrumen yang digunakan pada tahap pengambilan keputusan atas berbagai alternatif strategi hasil matriks SWOT adalah teknik Quantitative Strategic Planning Matriks (QSPM) untuk menentukan daya tarik relatif dari tindakan alternatif yang layak. Alternatifalternatif strategi yang dipertimbangkan untuk dapat diimplementasikan hasil analisis SWOT adalah sebagai berikut:

1. Strategi 1: Menyusun keputusan-keputusan teknis penyelenggaraan pemilihan yang disesuaikan dengan keadaan di Kabupaten Bogor dengan tetap perpedoman pada peraturan perundangundangan di atasnya

2. Strategi 2: Menyusun program-program penyampaian informasi dan sosialisasi yang lebih inovatif dengan memanfaatkan keberadaan komunitas dan organisasi masyarakat sebagai agen sosialisasi

3. Strategi 3: Meningkatkan sinergi di lingkungan internal serta mengintensifkan koordinasi dengan pemerintah daerah dan jajaran muspida lainnya

4. Strategi 4: Memanfaatkan teknologi informasi dalam menyebarkan informasi dan sarana sosialisasi sebagai salah satu alternatif efisiensi waktu dan keterbatasan personil

5. Strategi 5: Meningkatkan pelayanan pemberian informasi kepada masyarakat tentang Pemilu di Kabupaten Bogor melalui PPID

6. Strategi 6: Memperbanyak kegiatan sosialisasi secara tatap muka di berbagai wilayah di Kabupaten Bogor untuk menekan penyebaran berita hoax melalui teknologi informasi

7. Strategi 7: Melakukan kajian-kajian atas masalah yang diperkirakan akan timbul dari persepsi yang berbeda atas isi peraturan perundang-undangan untuk mendapatkan solusi awal

8. Strategi 8: Melakukan monitoring dan evaluasi atas kegiatan penyebaran informasi dan sosialisasi
Tabel 6. Perhitungan prioritas strategi dengan QSPM

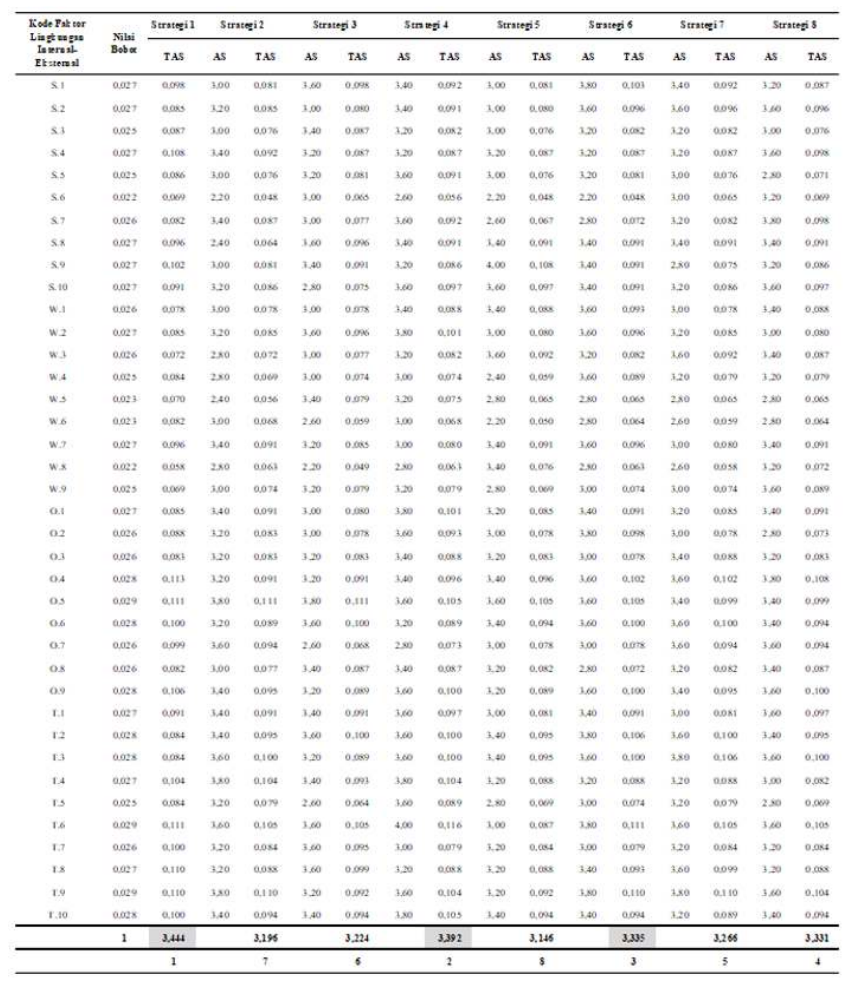

Gambar 6. Alur penentuan prioritas strategi dengan penghitungan TAS alternatif strategi menggunakan QSPM

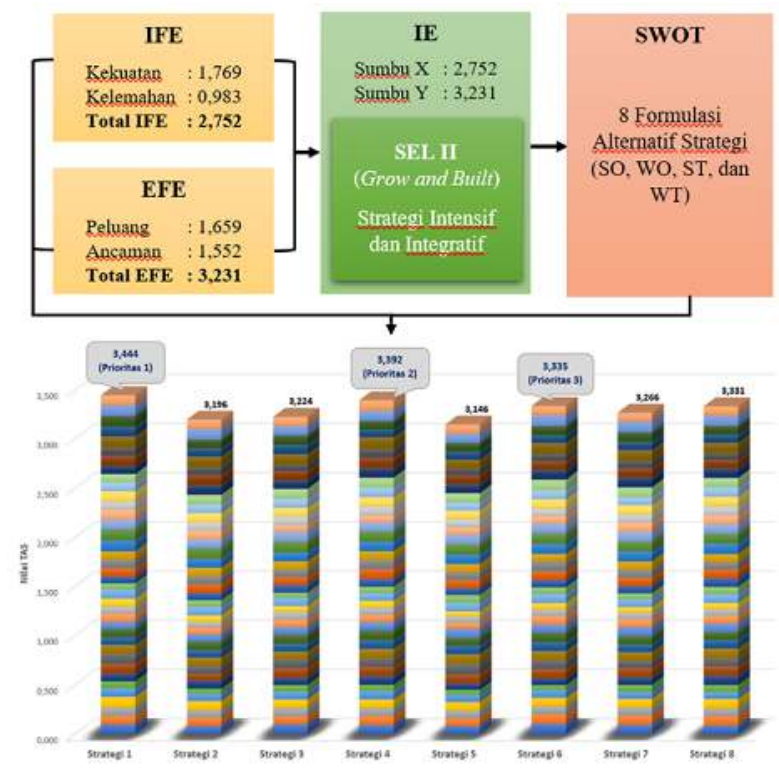

Alternatif strategi yang terpilih sebagai alternatif utama atau alternatif prioritas 1 adalah Strategi 1 dengan skor 3,444 yaitu menyusun keputusan-keputusan teknis penyelenggaraan pemilihan yang disesuaikan dengan keadaan di Kabupaten Bogor dengan tetap perpedoman pada peraturan perundang-undangan di atasnya, hal ini 
menjukan bahwa peraturan dalam bentuk keputusan-keputusan teknis penyelenggaraan pemilihan sangat penting untuk mempertegas dan memberikan aturan yang lebih spesifik sesuai dengan keadaan di Kabupaten Bogor serta dapat membuat rencana kerja program-program kegiatan lebih jelas dan terarah termasuk program-program kegiatan untuk peningkatan partisipasi pemilih. Alternatif strategi prioritas kedua yang dapat diimplementasikan adalah Strategi 4 dengan skor TAS 3,392, yaitu memanfaatkan teknologi informasi dalam menyebarkan informasi dan sarana sosialisasi sebagai salah satu alternatif efisiensi waktu dan keterbatasan personil. KPU Kabupaten Bogor dapat memanfaatkan teknologi informasi untuk menyampaikan berbagai informasi mengenai pemilihan dan sebagai sarana sosialisasi dengan jangkauan yang luas secara serentak dalam waktu yang singkat, sehingga KPU Kabupaten Bogor dapat mengefisenkan jumlah personil dan waktu yang terbatas jadwal tahapan. Alternatif strategi prioritas ketiga dengan skor TAS 3,335 adalah Strategi 6, yaitu memperbanyak kegiatan sosialisasi secara tatap muka di berbagai wilayah di Kabupaten Bogor untuk menekan penyebaran berita hoax melalui teknologi informasi. Penyebaran informasi dengan memanfaatkan teknologi informasi juga harus diiringi dengan kegiatan tatap muka terutama dalam melakukan sosialisasi agar masyarakat mendapatkan informasi yang utuh dan benar.

\section{Simpulan}

Berdasarkan hasil penelitian yang dilakukan di KPU Kabupaten Bogor dalam upaya meingkatkan partisipasi pemilih pada Pemilu 2019 berdasarkan keadaan pada Pemilihan Bupati dan Wakil Bupati Bogor Tahun 2018, maka diperoleh kesimpulan, yaitu: 1) Identifikasi lingkungan KPU Kabupaten Bogor terdiri dari lingkungan internal dan eksternal yang manghasilkan kekuatan, kelemahan, peluang dan ancaman. Identifikasi lingkungan internal menghasilkan 10 faktor kekuatan dan 9 faktor kelemahan yang dituangkan dalam matrik IFE dengan total skor 2,752 dan identifikasi lingkungan eksternal menghasilkan 9 faktor peluang dan 10 faktor ancaman yang dituangkan dalam matrik EFE dengan total skor 3,231, sehingga posisi KPU Kabupaten Bogor pada Matrik IE berada pada sel II, yaitu grow and build dengan rumusan strategi yang sesuai adalah strategi intensif dan integrative; 2) Hasil identifikasi lingkungan internal dan eksternal dianalisis dengan menggunakan SWOT dan mengasilkan delapan alternatif strategi yang terdiri dari masing-masing 2 alternatif strategi untuk strategi SO, WO, ST, dan WT; 3) Strategi yang dapat diimplementasikan sebagai hasil penghitungan nilai atraktif setiap alternatif strategi melalui QSPM, mengasilkan strategi utama dengan nilai TAS 3,444 yaitu menyusun keputusan-keputusan teknis penyelenggaraan pemilihan yang disesuaikan dengan keadaan di Kabupaten Bogor dengan tetap berpedoman pada peraturan perundang-undangan di atasnya. KPU Kabupaten Bogor diharapkan dapat memperkuat dan memperjelas setiap program kerja melalui keputusan-keputusan teknis yang telah disesuaikan dengan keadaan di Kabupaten Bogor, sehingga program-program dari KPU RI dan KPU Provinsi yang sifatnya general dapat diatur lebih spesifik dan terarah baik dari sisi perencanaan maupun pelaksanaannya, termasuk untuk program kegiatan dalam rangka meningkatkan partisipasi pemilih pada Pemilu Tahun 2019. Selain itu KPU Kabupaten Bogor juga hendaknya lebih cepat meng-update berita/informasi pada web resmi KPU Kabupaten Bogor, sehingga masyarakat dapat menegatahui informasi terbaru dari sumber terpercaya. Selain itu, penyampaian informasi secara digital juga sebaiknya diimbangi oleh kegiatan sosialisasi tatap muka dengan memaksimalkan jadwal tahapan sosialisasi dan tetap memperhatikan jumlah pegawai dan urgensi kegiatan tahapan lain.

\section{Referensi}

Bakri. Politik dan Pengaruhnya terhadap Perekonomian. [Internet]. Diakses pada 16 Agustus 2018. Tersedia pada: http://aceh.tribunnews.com/ 2015/05/26/politik-dan-pengaruhnyaterhadap-perekonomian.

Budiardjo M. 2010. Dasar-Dasar Ilmu Politik. Jakarta (ID): Gramedia Pustaka Utama.

David FR, David FR. 2015. Manajemen Strategik: Suatu Pendekatan Keunggulan Bersaing-Konsep. Ed ke-15. Jakarta (ID): Salemba Empat.

Kurniawan E, Haikal AM. 2016. Membangun Kompetensi Dasar Kepemiluan untuk Komunitas Seri Modul Pelatihan. Jakarta (ID): Komisi Pemilihan Umum Republik Indonesia.

[KPU] Komisi Pemilihan Umum. 2014. Partisipasi Pemilih Pemilu 2014 dalam 
Angka. Jakarta (ID): Komisi Pemilihan Umum Republik Indonesia.

Muhammad S. 2013. Strategi Pemerintah: Manajemen Organisasi Publik. Jakarta: Penerbit Erlangga.

Munandar JM, et al. 2014. Pengantar Manajemen Panduan Komprehensif Pengelolaan Organisasi. Bogor (ID): IPB Press.

Nimmo D. 2010. Komunikasi Politik Khalayak dan Efek. Bandung (ID): Remaja Rosda Karya.

[PemkabBogor] Pemerintah Kabupaten Bogor. 2017. Kependudukan. [Internet]. Diakses pada 1 Agustus 2018. Tersedia pada http://bogorkab.go.id/index.php/page/det ail/17/kependudukan\#.W2wOYegzZEY.

Purnomo SH, Zulkieflimansyah. 2007. Manajemen Strategi. Jakarta (ID):
Lembaga Penerbit Fakultas Ekonomi Universitas Indonesia.

Rangkuti F. 2013. Analisis SWOT Teknik Membedah Kasus Bisnis: Cara Perhitungan Bobot, Rating, dan OCAI. Jakarta (ID): Gramedia Pustaka Utama.

Sugiyono. 2010. Statistik untuk Penelitian. Bandung (ID): Alfabeta.

Surbakti R. 2010. Memahami Ilmu Politik. Jakarta (ID): Grasindo.

Umar H. 2008. Strategic Management in Action. Yogjakarta (ID): Kanisius.

Wahid U. 2016. Komunikasi Politik Teori, Konsep, dan Aplikasi pada Era Media Baru. Bandung (ID): Simbiosa Rekatama Media 